Dragica Stojanovic, $\mathrm{MsC}^{1}$

Biljana Ilić, $\mathrm{MsC}^{2}$

University of Megatrend, Belgrade,

Faculty of Management, Zaječar

Zoran Simonovic, $\mathrm{PhD}^{3}$

Institute of Agricultural Economics, Belgrade
SCIENTIFIC REVIEW ARTICLE doi:10.5937/ekonomika1502093S

Received: March 3, 2015

Accepted: May 7, 2015

\title{
CO2 EMISSIONS TRADING AT THE STOCK EXCHANGE - QUALITY ENHANCEMENT OF TOURISM POTENTIAL, ECOLOGICAL AND ECONOMIC GROWTH
}

\begin{abstract}
Since climate changes have caused significant problems in the functioning of the modern world, human society and economics at the global level, it is inevitable to take appropriate protective measures. Climate change and its bad influence directly relate to the environment and indirectly to economic, i.e. tourist activities which are linked to natural potentials. For years, human or industrial activities have been emitting greenhouse gases into atmosphere, which have harmed the climate to a large extent. In order to prevent further pollution, permits for emitting greenhouse gases were introduced at various conferences on a global level. These permits are traded on the stock exchange so this paper gives an overview and description of $\mathrm{CO} 2$ emission trading. Such an indirect environmental protection provides the possibility of reducing harmful gasses emission into atmosphere, and thus less harming climate factors. The paper puts emphasis on the Kyoto Protocol, CO2 emissions market, situation and tendencies on the market and their influence on tourism.
\end{abstract}

Key words: Tourism potential, the Kyoto Protocol, ecological and economic development, CO2 emissions, emissions permits

JEL classification: Q00

\section{ТРГОВАҢЕ ЕМИСИЈАМА СО2 НА БЕРЗИ - ПОБОЉШАЫЕ ТУРИСТИЧКОГ И ЕКОЛОШКО ЕКОНОМСКОГ РАЗВОЈА}

\begin{abstract}
Апстракт
С обзиром да су климатске промене проузроковале значајне проблеме у функционисању савременог света, људског друштва и економије на глобалном нивоу, неминовно је предузимање одговарајућих мера заштите. Промена климе и њен лош утицај се непосредно односе на природну средину а посредно
\end{abstract}

\footnotetext{
${ }^{1}$ dragica.stojanovic@fmz.edu.rs

2 biljana.ilic@fmz.edu.rs

3 zoki@medianis.net
} 
и на привредне, односно туристичке делатности које су везане за природне потенцијале. Људска делатност, односно индустријска постројења су годинама уназад емитовала у атмосферу стакленичке гасове, који су у великој мери нарушили климу. На разним Саветованима на глобалном нивоу, у ичиьу спречавање даљег загађена, уведене су дозволе за испуштање стакленичких гасова. Овим дозволама се тргује на берзи, те је у раду дат преглед и опис трговања емисијама $\mathrm{CO}_{2}$. Овако посредна заштита животне средине пружа могућност за смањење емитовања штетних гасова у атмосферу, те на тај начин и мањем нарушавању климатских фактора. У раду је стављен акиенат на Куото Протокол, тржиште емисијама $\mathrm{CO}_{2}$, стање и тенденције на тржситу и юихов утицај на туризам. Рад повезује тематске области везане за берзанско трговање дозволама, заштиту природне средине и нарушавање климатских фактора, те даје ново економскио-еколошко сагледавање туризма као једне од важнијих грана светске привреде.

Кључне речи: Туристички потенцијал, Куото протокол, економско еклошки развој, Емисија СО2, емисионе дозволе

\section{Introduction}

Nowadays, climate change is the biggest and most serious challenge for the planet, the environment and global economy. Climate changes influence the quality of tourist potentials of a country, as well as the economic and ecological development of the country indirectly. There are evident scientific proofs that high concentrations of gases in the atmosphere which cause GHG - greenhouse gases effect are responsible for global warning. In recent years, tourism has been a branch of economy that brings huge profit globally. But, if we want tourist destinations to keep their primary role of human relaxation and health, it is necessary to save and preserve them from pollution as much as we can. Atmospheric, or climate changes, indirectly affect the attendance of a certain tourist destination since either the surplus or shortage of rainfall during the year, or too much heat or too cold winters, can cause that the attendance of a specific place of region decreases. The economic effect of tourism decreases in this way, too. Atmospheric changes are also affected by the emission of harmful gases, so it is necessary to take urgent measures in order to reduce their harmfulness. The trading on the stock exchange with quotas or permits is based on the setting or approving the maximum allowed limit of $\mathrm{CO} 2$ emission by relevant institutions. The bottom line is that the companies that emit $\mathrm{CO} 2$ in larger quantities than they are allowed pay for extra pollution, while the ones that emit less are awarded by selling the unused quotas.

\section{The Kyoto Protocol in response to frequent ecological disasters}

It is believed that global warming is mostly caused by the emission of greenhouse gases into the atmosphere as a result of human activities, especially the change in using 
land by deforestation, as well as fossil fuels burning (coal, oil and gas) (European Commission, 2007). The development complies with the requirements and limitations of nature, involves correlation of economic and environmental policy at all levels of society and its integration with modern international trends (Mihajlović, Ilić, \& Simonović, 2013). The mentioned problems called for a global solution (Cavoski, 2005). The first step towards reducing greenhouse gases emissions (GHG emissions) was taken on 9 May, 1992, when the United Nations Framework Convention on Climate Change (UNFCCC) was adopted. The second step was the Kyoto Protocol, adopted at the third Conference of the Parties of the United Nations Framework Convention on Climate Change, held in December 1997 in Kyoto, Japan. The Protocol was put into effect on 16 February, 2005. To be put into effect, at least 55 counties making up at least $55 \%$ of pollutants were needed to ratify the Protocol. The main difference between the Protocol and the Convention is that the Convention encourages industrialised countries to stabilise the greenhouse gases emission, and the Protocol commits them to doing so.

The flexible mechanisms of the Kyoto Protocol are designed to motivate further reduction of emissions of greenhouse gases, primarily by increasing the economic feasibility of introducing measures that are in line with the objectives of the Protocol. The flexible mecanisms of the Kyoto Protocol are designed to further motivate the reduction of greenhouse gases emission, primarily by increasing economic feasibility of introducing measures in compliance with the objectives of the Protocol. Namely, The developed countries (also called Annex I parties) are allowed to, instead of on their territory, if they consider that it is more cost-effective, to implement projects with the objective of fulfilling their obligations under Annex B in the territories of other countries signatory to the Kyoto Protocol, either developed or developing countries (which are also called non-Annex I parties). These mechanisms are based on the principles of openness and transparency with intensive use of the Internet and other advanced technologies (Caring for Climate, 2005). There are three such mechanisms:

1. The Clean Development Mechanism is one of the mechanisms for implementing the Kyoto Protocol (Clean Development mechanism - CDM). Reduced emissions of greenhouse gases created by using this mechanism is expressed as Certified Emission Reductions (Certified Emission Reductions, CERs) (Damnjanovic and Tufegdzic).

2. The joint implementation mechanism allows countries listed in Annex I to meet part of their commitments through the implementation of projects aimed at reducing emissions of greenhouse gases in the territories of other countries, which are also Parties to Annex I, in compliance with the aforementioned rules and principles. Reducing emissions in such projects is expressed in units of emission reductions (Emission Reduction Units, ERUs).

3. Emissions trading is the third mechanism which, in compliance with certain rules and restrictions, allows the countries listed in Annex I to "sell" to other countries, parties of Annex I the excess reduction (relative to the defined). This mechanism allows trade with other means, such as CERs or ERUs (Stefanović, Ćojbašić, Vučković, \& Stojiljković, 2007).

The ratification applies in particular to the tendencies that are associated with the negotiations on the future direction of the international community in the field of climate 
change and assuming responsibilities that are (not) in accordance with the possibilities of the economy and society (Todić, Grbic, 2014). The question is how to prevent the emission of carbon dioxide? Prospects of further development of the EU ETS by 2050 are shown in Figure 1.

Figure 1. Prospects of further development of the EU ETS cap by 2050

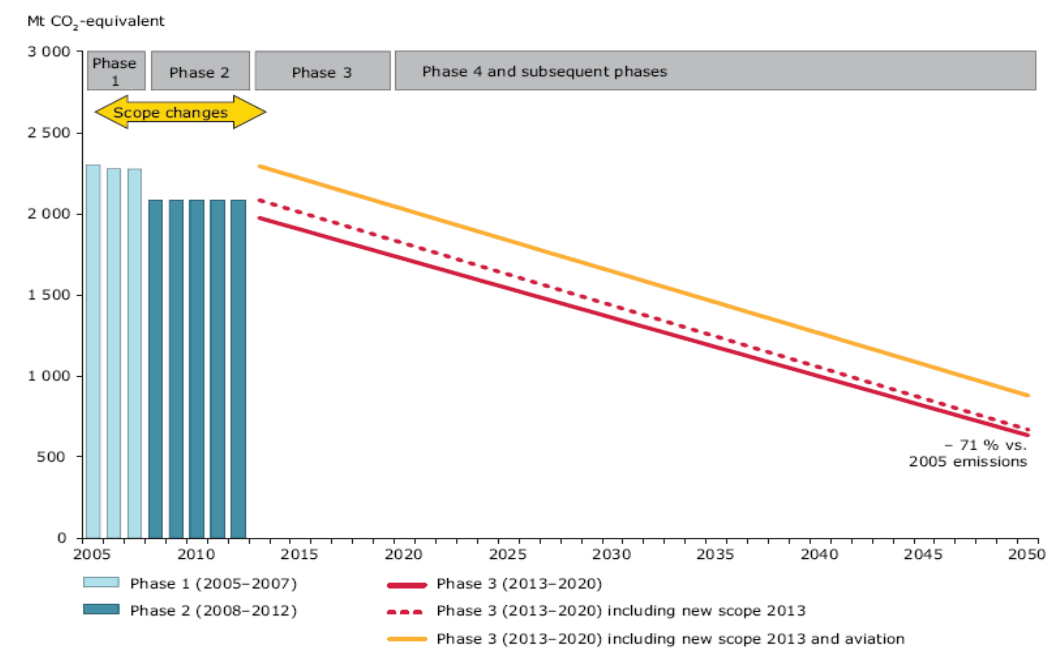

Source: European Environment Agency, 2013 Trends and projections in Europe 2013 - Tracking progress towards Europe's climate and energy targets until 2020, Copenhagen, Denmark, p. 26.

The answer can be found in the following (Petrovic, 2013): improving the efficiency of energy production and consumption; energy conservation and saving; use of non polluting and renewable energy sources; fines and fees; market mechanism.

\section{CO2 emissions market}

The emergence of CO2 markets is linked to the period of the early 90's, when the great attention was paid to the protection and preservation of the living and working environment. The very need for such a mechanism regulating emissions is found in the unity of political, scientific (environmental) and economic objectives. Gas emissions market differs from other commodity markets insofar as the GHG emissions or loans (gases that cause the greenhouse effect - greenhouse gases) can not be stored or transferred to the next year, but must be utilized during the current year. This solution is applied because the mechanism for reducing emissions has been designed to reduce annual emissions by a certain percentage in relation to the level of 1990. Therefore, each year annual emissions are independently compared to 1990 levels and thus there is no possibility of the disruption of business in the market on the basis of, for example, warmer winters in one country (Aziakou, 2006). Transactions of CO2 emissions, which take place in the greenhouse gases emissions market, can generally be divided into: Spot 
transactions - delivery and payment of permits shall be made in a short period of time immediately after the conclusion of the agreement; "Forward Settlement" - delivery and payment of emissions permits is postponed for a future moment, which is defined at the moment of trade; "Options" - contracts that give buyers / sellers the option, but not the obligation of performing a transaction before or exactly on a specific date. The price of emissions permits is predetermined, as well as the date of the transaction, whereby customers bear the costs of flexibility of such contracts; project investing - customers can also choose to invest in projects that will result in the emissions reduction. Greenhouse gases emissions markets can be organized as: Stock Exchange (Exchange Market) and "over the counter markets "(Over the counter, OTC) - the market is composed of actors who are not members of the official stock exchange. The trading is not performed regularly as on the stock market, transactions are done through a broker by phone or computer, and the terms of the contract are bilaterally negotiated by two involved parties or standardized agreements are used. After the Great Depression, this market came to be regulated, too.

However, the successful establishment of a system of emissions trading depends on certain conditions. First, there needs to be a sufficient number of participants on the market both for buying and selling. Without a sufficient number of participants, the price of permits will not show the true state of supply and demand. The second condition is low transaction costs of permits trading. Otherwise, neither sellers nor buyers can find interest in trading. Third, for the trade system to work properly there must be a strong regulatory system for issuing emissions permits and, in general, from the system of emissions monitoring, verification of emission reductions and tracking emissions register (Emissions Trading) (Aziakou, 2002).

Emissions trading system in general can be organized in two ways (Hrncevic, 2008). These are "cap \& trade" system and "baseline \& trade" system. The main difference between these systems of emissions trading is in setting emissions restrictions and the method of allocating licenses. In the cap \& trade system a competent body sets framework emissions restrictions for all the emitters in the trading system and based on that framework, the body sets unique restrictions for each emitter in the system. The baseline $\&$ trade system sets equal restrictions for all companies for the emission of greenhouse gases. Although the cap \& trade emissions trading system is considered more efficient than baseline $\&$ trade system there are still some drawbacks and limitations. More precisely, these are the unstable and unpredictable prices of permits (the possible solution is the so-called "forward transactions", high administrative and legal costs, the allocation of emissions permits and the possibility of corruption. However, as the main drawback of the cap \& trade system, critics point out the assessment of actual emissions of companies and consider that environmentally better results are achieved by the introduction of the greenhouse gases emission tax. Accordingly, the main difference between the cap \& trade system of emissions trading and taxation systems is in setting emissions restrictions (cap) which define the amount of emissions to be emitted, while the prices of the emission permit and fines are variable (Carbon emissions trading). Emissions trading system involves the purchase or sale of emission permits that can be obtained in two ways. The first method of procurement is the purchase from the relevant institution providing primary emissions, and the purchase of licenses takes auction system. Another possibility of obtaining emission permits is the use of carbon credits that were obtained by CDM projects. 
In spite of the opinion that this market has good prospects, the method of risk management in purchasing is still unclear. Specifically, in these markets there are several types of risk among which are: country risk-refers to investments in CDM projects in politically unstable countries; quality risk - refers to non-compliance with the so called CDM golden standards; delivery risk - refers to introduction of new untested technologies which may not be able to fulfil the predicted $\mathrm{CO} 2$ emission reduction; market risk - the risk of negative effects on financial results and bank capital due to changes in the value of the portfolio of financial instruments. No matter the risk in $\mathrm{CO} 2$ emissions trading, there is the possibility of decreasing the unwanted consequences caused by trade thanks to a large number of financial instruments such as the derivatives (futures and options).

\section{Status and trends in the $\mathrm{CO} 2$ market}

Although the EU permits could be used in accordance with the goals of reducing greenhouse gas emissions, those who were trading looked for an opportunity to earn as much as possible on these transactions. One of the dominant financial instruments which have played an important role in the fight against the risks were options. Between 2007 and 2008, options trading volume increased by 5 times. It continued growing in the following years but, due to the economic crisis, the growth was much slower which had impact on the market price of emission permits (CER - Certified Emissions Reduction and VER). Compared to 2009, when the price of emission permits recorded a decline, in the coming period it began to growth. More specifically, in January 2010 it amounted to €12.85/t CO2, and in January 2011, €14.97/t CO2.

Figure 2. The prices of emission permits in the period 2010-2015

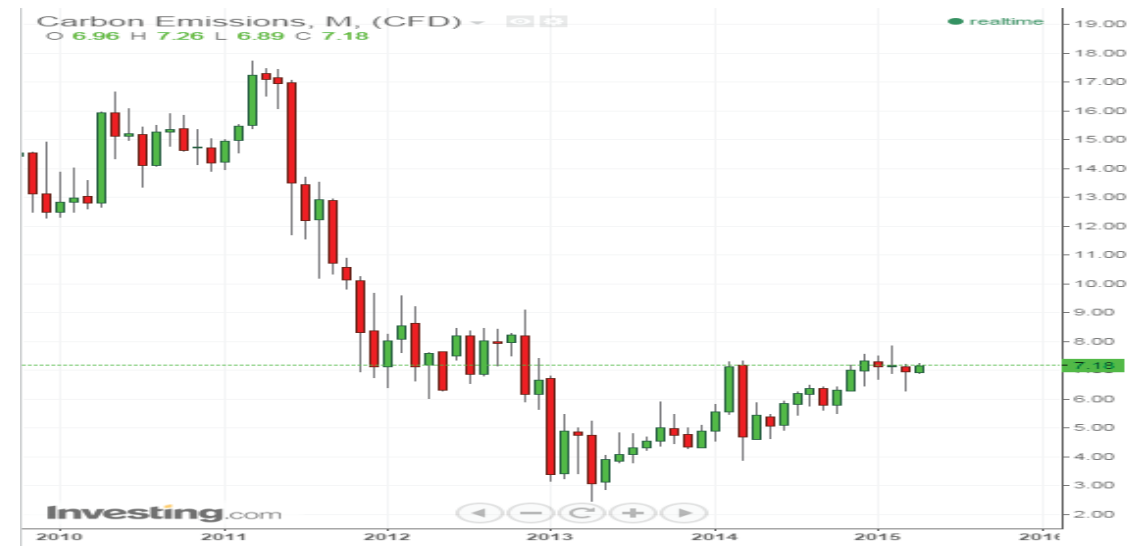

Source: Investing. Com, Carbon Emissions Streaming Chart, http://www.investing.com/ commodities/carbon-emissions-streaming-chart

However, after October 2011, again a decline is seen in the price of emission permits so that in January 2012 it amounted to $€ 8.06 / \mathrm{t} \mathrm{CO} 2$. With smaller and larger fluctuations in the following years the price of emission permits decreases so that in December 2014 it was at $€ 7.34 / \mathrm{t} \mathrm{CO} 2$ (Koch, 2014). Market prices for emission permits in the period from January 2010 to January 2015 are shown in Figure 2. Along with increased awareness of the impact of emissions on the environment, in addition to the 
slow growth of the market, from the beginning of trading to date, the volume of $\mathrm{CO} 2$ emissions trading scheme records a steady growth (Figure 3).

Figure 3.Trading by EU Emissions (Million tones)

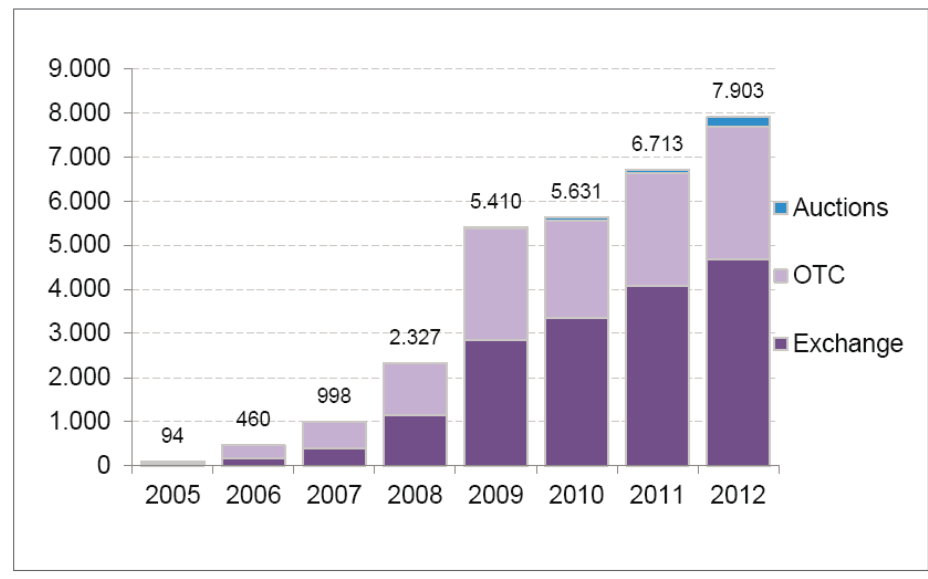

Source: European Comission (2013) The EU Emissions Trading Systems (EU ETS), Brussels, p. 6.

Bearing in mind the above mentioned facts, ICE Futures Europe can serve as a good example with CO2 emissions trading having begun in 2005. Analyzing the volume of trading on the ICE Futures Europe it can be concluded that the volume of trading in 2014 increased by about 19 times compared to 2006. As for the types of contract, the most used were futures and options (Table 1).

Table 1. Monthly trad. volume of CO2 emissions - contract 2006- 2014 (lot:1000t CO2)

\begin{tabular}{|c|c|c|c|c|c|c|c|c|c|c|c|c|c|c|c|}
\hline $\begin{array}{c}\text { Measure } \\
\text { lot }\end{array}$ & 2006 & & 2007 & & 2008 & & 2009 & & 2010 & & 2011 & & 2012 & 2013 & 2014 \\
\hline & Futures & Options & Futures & Options & Futures & Options & Futures & Options & Futures & Options & Futures & Options & Futures & Futures & Futures \\
\hline Jan & 33,931 & 0 & 60,007 & 1,150 & 126.593 & 44,570 & 253.156 & 34,851 & 382,098 & 34,325 & 361,367 & 79,704 & 561,715 & 756,384 & 837,420 \\
\hline Feb & 26,638 & 0 & 60,786 & 2,050 & 117.493 & 22,380 & 386.064 & 61,071 & 397,371 & 61,571 & 374,374 & 71,110 & 624,442 & 934,316 & 944,117 \\
\hline Mar & 22,331 & 0 & 71,879 & 1,950 & 111.482 & 16,065 & 491.545 & 47,457 & 397,083 & 79,350 & 699,001 & 68,543 & 642,320 & 759,394 & $1,146,937$ \\
\hline April & 41,146 & 0 & 57,826 & 1,450 & 159.373 & 31,270 & 444.489 & 71,607 & 624,034 & 114,371 & 360,705 & 30,360 & 549,585 & 876,947 & 729,472 \\
\hline Maj & 53,376 & 0 & 75,803 & 1,910 & 123.394 & 18,614 & 372.047 & 59,190 & 613,471 & 78,061 & 432,536 & 25,330 & 557,175 & 532,568 & 593,552 \\
\hline Jun & 22,553 & 0 & 88,866 & 2,515 & 244.010 & 50,811 & 422.050 & 42,700 & 513,168 & 72,128 & 766,526 & 65,490 & 590,066 & 823,609 & 556,853 \\
\hline Jul & 29,602 & 0 & 119,268 & 6,790 & 319.857 & 26,445 & 433.031 & 37,883 & 451,553 & 72,370 & 599,834 & 72,950 & 734,516 & 541,914 & 732,165 \\
\hline Aug & 27,270 & 0 & 94,369 & 8,750 & 196.435 & 11,615 & 253.850 & 29,550 & 340,554 & 54,155 & 731,695 & 67,805 & 616,964 & 328,945 & 431,408 \\
\hline Sep & 38,212 & 0 & 88,561 & 10,900 & 244.698 & 20,165 & 403.268 & 31,210 & 361,944 & 91,886 & 566,027 & 47,057 & 709.204 & 653.681 & 668,245 \\
\hline Oct & 51,124 & 410 & 102,008 & 5,735 & 390.617 & 21,735 & 415.611 & 20,544 & 393,722 & 56,057 & 561,522 & 81,050 & 953,207 & 690,302 & 633,325 \\
\hline Nov & 65,325 & 50 & 88,930 & 9,475 & 298.511 & 23,945 & 398.754 & 40,220 & 496,600 & 49,300 & 751,329 & 99,142 & $1,077,565$ & 743,826 & 721,081 \\
\hline \multirow[t]{2}{*}{ Dec } & 40,851 & 100 & 72,592 & 4,751 & 166.592 & 22,951 & 342.057 & 31,414 & 373,092 & 57,499 & 578,982 & 77,922 & 870,282 & 641,106 & 651,379 \\
\hline & 452,359 & 560 & 980,895 & 57,426 & $2,499,055$ & 310,566 & $4,615,922$ & 507,697 & $5,344,690$ & 821,073 & $6,783,898$ & 786,463 & $8,487,041$ & $8,282,992$ & $8,645,954$ \\
\hline SUM & & 453 & & $1,038,321$ & & $2,809,621$ & & $5,123,619$ & & $6,165,763$ & & 7570361 & 8.487 .041 & 8.282 .992 & 8.645954 \\
\hline
\end{tabular}

Source:https://beta.theice.com/marketdata/reports/ReportCenter.shtml?reportId $=10 \& c$ ontractKey=20\#report/7 


\section{The influence of climate factors on tourism}

Experts of the International Energy Agency have warned and drawn attention to the fact that annual carbon dioxide emissions should not exceed 32 gigatonnes by 2020. According to recent estimates, the emissions reached 30.6 gigatons during 2010. So it can be concluded that the future looks bleak for all branches of the economy and for the normal functioning of life on the Earth, as well (http:// www.slobodnaevropa.org /archive/news/latest/500/500. $\mathrm{html}$ ? id=24209348). The consequence of increasing global temperatures is seen in sea level rise and changing patterns of precipitation. This leads to the expansion of subtropical deserts. The greatest warming is in the Arctic, and a constant melting of glaciers and sea ice can be expected. Other phenomena that are predicted are an increase in the intensity of extreme weather events, species extinction, as well as changes in agricultural yields. The First International Conference on Climate Changes and Tourism was held in Tunisia (Djerba) in April 2003, organised by the World Tourism Organisation. It was a great opportunity for all stakeholders in tourism, as well as scientists, to exchange views on the consequences, opportunities and risks that are placed in front of the tourism sector as a result of changes in the global climate. The result of the conference, the Djerba Declaration on Climate Change and Tourism, recognized the relationship between climate change and tourism. On one hand, tourism is affected by climate change, especially when it comes to tourist destinations in coastal, mountainous, arid and floodplain areas, and on the other, tourism also contributes to the causes of climate change, particularly through emissions through traffic and other types of energy use. Climate changes may affect tourism in several ways: the variable and unstable weather conditions complicate tourism operations and planning; natural weather disasters can harm tourism infrastructure, natural and cultural heritage and local communities; much of the tourist infrastructure is located in sensitive areas; climate changes may affect the level of tourist comfort, as well as the number of their activities; the rise of sea level and temperatures threaten coastal and island destinations, as well as the port cities; climate changes may affect natural habitats and biodiversity, which are the main attraction of eco tourists and nature lovers; change in rainfall and hydrological cycle may affect the availability of freshwater resources in the destination, which is among the basic needs of tourists; reduced snowfall directly affects the mountain and ski tourism. Many tourist activities (skiing, swimming, wildlife, tourism based on nature) require specific weather conditions. A small increase in winter temperatures, for example, will eliminate ski center on the lower slopes of the Alps. The reaction of tourists to climate change can be a negative impression about the attractiveness of the destination (for example, dead coral, scarcity of species, habitat loss).

\section{Advantages of Serbian entry on issuance market in the development of tourism potentials}

The necessity of the ratification of the document and its implementation is quite obvious. The Republic of Serbia is a member of the Kyoto Protocol since 17 January 2008. This applies in particular to the tendencies that are associated with the negotiations on the future direction of the international community in the field of climate change and assuming responsibilities that are (not) in accordance with the possibilities of the economy and society (Todic, Grbic, 2014). Increasing energy efficiency by using international emissions market in one country can result in: attracting 
new technologies, encouraging innovation in the economy, improving competitiveness and encouraging long-term economic growth. In this way, global GHG emissions market represents a real opportunity for Serbia to improve its energy efficiency (Avlijas, 2007). This would ensure not only the reduction of emissions that pollute the environment or cause climate changes, but also the economic incentive for the introduction of new energy-efficient technologies and the use of renewable energy resources. In accordance with the foregoing, it can be concluded that in the global emissions market, Serbia could convert its lack of energy efficiency into a comparative advantage. What is certainly more important is that the implementation of activities in this area in the way they are implemented in the EU would enable Serbia, with some reasonable and costeffective investment, to create new jobs and new areas of work, but also the competitiveness of national companies in the EU and international market. In other words, only the fulfillment of the basic requirements of the EU package, primarily in terms of increasing the use of renewable energy and energy efficiency, together with the involvement in the emissions trading system, can provide Serbia with the placement of domestic products in the EU market and thus the survival and positive local business operations of domestic companies (Bozanic, 2012). That is certainly the way forward for Serbia towards sustainable tourism.

\section{Conclusion}

The very essence of the idea of formation of $\mathrm{CO} 2$ emissions market had noble intentions relating to environmental protection. Many problems in the world emerging and disappearing from year to year, have been diverting attention from the issues that are crucial to human survival (climate change caused by anthropogenic influences). The CO2 market along with other mechanisms of economic and market regulation will inevitably become a decisive factor of environmental protection in a market economy. Taking into account the harmful gases emissions in Serbia, by joining the $\mathrm{CO} 2$ market Serbia will gain comparative advantage for two different reasons. On one hand, Serbia will directly benefit from the introduction of limits in harmful gases emissions through environmental protection, and on the other hand, it will generate additional public revenues. The only problem occurs due to the additional fiscal burden that will fall on the private sector, which has not been in the best position. But the global CO2 market represents a rare opportunity for Serbia to be actively involved in sustainable development, increase energy efficiency and make significant steps in further economic expansion.

\section{References}

Avlijaš, S. (2007). Pod lupom Može li Kjoto protokol doprineti većoj energetskoj efikasnosti u Srbiji?, Kvartalni monitor 8, januar-mart, pp. 56-64.

Aziakou, G. (2006). "Britain Urges Global Carbon Trading to Spur Eco-Healthy Growth", Terra Daily, 21 ${ }^{\text {st }}$ April, Internet: http://www.terradaily.com/reports/ Britain_Urges_ Global_Carbon_Trading_To_Spur_EcoHealthy_Growth.html. (15.01.2015.)

Božanić, D. (2012). Zahtevi Ev. zakon. u borbi protiv klim. prom., Internet:http:// www.bos.rs/ceiblog/danijelabozanic/742/2012/08/22/zahtevi-evropskogzakonodavstva-u-borbi-protiv klimatskih-promena-.html. (17.01.2015.) 
Caring for Climate, (2005). A Guide to the Climate Change Convention and the Kyoto Protocol, Climate Change Secretariat (UNFCCC), Bonn, Germany.

Čavoški, A., (2005). Kjoto protokol u svetlu učestalih ekoloških katastrofa, Stručna mišljenja, Internet: http://www.lawdem.org/200558c2.pdf (17.01.2015.)

Damnjanović, M., Tufegdžic, D. Nauka pod lupom, Internet: http:// www.kmhem.net/ archives/o3/kjoto/ (17.01.2015.)

Evropska komisija, (2007). Klimatske promene: izazovi za poljoprivredu, See: http:// www.ipcc.ch Climate Change. (15.01.2015.)

European Comission, (2013). The EU Emissions Trading Systems (EU ETS), Brussels p. 6.

European Environment Agency, (2013). Trends and projections in Europe 2013 Tracking progress towards Europe's climate and energy targets until 2020, Copenhagen, Denmark, p. 26.

EurActiv.rs, (2011). Krađa dozvola za zagađenje ugljen-dioksidom u EU, available at: http://www.euractiv.rs/odrzivi-razvoj/968-kraa-dozvola-za-zagaenje-ugljendioksidom-u-eu.(19.01.2015.)

Hrnčević, L. (2008). Doctoral dissertation: Analiza utjecaja provedbe Kyoto protokola na naftnu industriju i poslovanje naftne tvrtke, Zagreb.

ICE Futures Europe, Available at: https //beta.theice.com./marketdata /reports/ ReportCenter.shtml?reportId=10. (18.01.2015.)

Investing. Com, Carbon Emissions Streaming Chart, http:// www.investing.com / commodities/carbon-emissions-streaming-chart (18.01.2015.)

Klimatske promene i turizam, available at: http://www.lovetravel.rs/zelena-planeta/ klimatske-promene-i-turizam (18.01.2015.)

Koch, N., (2014). Dynamic linkages among carbon, energy and financial markets:a smooth transition approach. Applied Economics, 46(7),715-729.

Mihajlović, D., Ilić, B., \& Simonović, Z. (2013). Razvoj održive ekonomije prirodnih resursa u skladu sa ekološkim zahtevima. Ekonomika, 59(4), 10-21.

Mehanizam čistog razvoja - Clean Development Mechanisam - CDM, Internet: http:// www.met.gov.sb/clean_development_mechanism.htm (17.01.2015.)

Opasnost od porasta emisije štetnih gasova, available at: http: //www.slobodnaevropa. org/archive/news/latest/500/500.html?id=24209348 (15.01.2015.)

Petrović, A. (2013). Analiza troškova korišćenja biomase za proizvodnju električne energije, Univerzitet u Beogradu, Masinski fakultet, Beograd.

SEE Institute, Emisija ugljenika po jedinici BDP/a merenog paritetom kupovne moći u 2009. godini, Internet: http://www.see-institute.org/srpski/energetski-profil-rs (17.01.2015.)

Stefanović, M. G., Ćojbašić, R. Lj., Vučković, D. G., M.M.Stojiljković, M. M. (2007). Emisija $\mathrm{CO} 2$ u regionu zemalja zapadnog balkana, Internet: http://simterm. masfak.ni.ac.rs./procedings/132007/papers/sessions/6_Zastita_zivotne sredine/6-6/stefanovic1 pdf. (15.01.2015.)

Todić D., Grbić, V. (2014). Zemlje u razvoju i politika u oblasti klimatskih promena, Economics, 56(3), 315-331. 